\title{
Sabit doz inhale kortikosteroid, uzun etkili beta-2 agonist ve uzun etkili muskarinik reseptör antagonisti (iKS/LABA/LAMA) kombinasyonunun astım tedavisindeki yeri
}

\author{
Esra ÜNSAY METAN(ID) \\ Sevim BAVBEK(ID)
}

Ankara Üniversitesi Tıp Fakültesi, Göğüs Hastalıkları Anabilim Dalı, Alerji ve Klinik İmmünoloji Bilim Dalı, Ankara, Türkiye

Division of Allergy and Clinical Immunology, Department of Chest Diseases, Ankara University Faculty of Medicine, Ankara, Turkey
Makale atıfi: Ünsay Metan E, Bavbek S. Sabit doz inhale kortikosteroid, uzun etkili beta-2 agonist ve uzun etkili muskarinik reseptör antagonisti (iKS/LABA/LAMA) kombinasyonunun astım tedavisindeki yeri. Tuberk Toraks 2021;69(3):369-379.

\section{Yazışma Adresi (Address for Correspondence)}

\section{Dr. Sevim BAVBEK}

Ankara Üniversitesi Tıp Fakültesi,

Göğüs Hastalıkları Anabilim Dalı,

Alerji ve Klinik İmmünoloji Bilim Dalı,

ANKARA - TÜRKIYE

e-mail: bavbek@medicine.ankara.edu.tr

OTelif Hakkı 2021 Tüberküloz ve Toraks. Makale metnine

www.tuberktoraks.org web adresinden ulasslabilir.
Öz

Sabit doz inhale kortikosteroid, uzun etkili beta-2 agonist ve uzun etkili muskarinik reseptör antagonisti (IKS/LABA/LAMA) kombinasyonunun astım tedavisindeki yeri

Astımın etkin tedavisi, hastaların hayat kalitesini artırmak ve ataklar nedeni ile hastane başvurularını azaltmak açısından büyük önem taşımaktadır. Astımlı hastalarda parasempatik aktivite artmıştır. Bu durum hava yolu obstrüksiyonunun reverzibil olma potansiyeline sahip en önemli parçalarından birini oluşturur. Inhale kortikosteroid (iKS), uzun etkili beta-2 agonistler ("Long acting beta-2 agonists, $L A B A$ ") ve uzun etkili muskarinik antagonistler ("Long acting muscarinic antagonists, LAMA") arasındaki sinerjik etkileşime dair kanıtlar LAMA'nın astım tedavisinde kullanılmasını desteklemektedir. "Global Initiative for Asthma (GINA)" basamak 4'te öncelikli önerilen tedavilerin uygulanması ve risk faktörlerinin kontrol edilmesine rağmen astımı kontrol altında olmayan ve sık atak öyküsü olan hastalarda ek tedavi olarak eklenen tiotropium ile başarılı sonuçlar alınmıştır. Bu durum iKS/LABA/ LAMA sabit doz tedavilerinin astımda kullanılması konusunda çalışmaların başlamasına neden olmuştur. Kısa süre önce yayımlanan üç randomize kontrollü çalışmada iKS'lere $L A B A$ ve $L A M A$ eklenerek oluşturulan sabit doz kombinasyonların herhangi bir etken maddenin dozunu artırmaya gerek kalmadan astım hastalarında solunum fonksiyonlarında iyileșme ve atak sıklığında azalma sağladığı gösterilmiştir. Bu derlemede astımda LAMA'ların etki mekanizmaları özetlendikten sonra güncel veriler eşliğinde sabit doz iKS/LABA/LAMA'nın günlük pratikte astım tedavisinde potansiyel kullanımı değerlendirilmiştir.

Anahtar kelimeler: Astım; Inhale kortikosteroid; uzun etkili beta-2 agonist; uzun etkili muskarinik reseptör antagonisti; sabit doz iKS/LABA/LAMA 


\begin{abstract}
The role of fixed dose combinations of inhaled cortikosteroids, long acting beta-2 agonists, and long acting muscarinic antagonists (ICS/LABA/LAMA) in the treatment of asthma

The effective treatment of asthma is important in terms of improving the quality of life and decreasing the number of hospital admissions due to acute exacerbations. Parasymphatic activity is increased in patients with asthma. This is one of most important part of airway obstruction which has a great potential for reversibility. The evidence about the synergic interaction between inhaled corticosteroids (ICS), long acting beta-2 agonists (LABA), and long acting muscarinic antagonists (LAMA) encourages the use of LAMA in asthma. Tiotropium treatment was found to be successful in patients with recurrent exacerbations in whom asthma was uncontrolled despite treatment with other add on treatments that were recommended at GINA step 4. These findings triggered several clinical studies on fixed dose ICS/LABA/LAMA for asthma treatment. Three studies that have been published recently showed that fixed dose ICS/LABA/LAMA improved the lung functions and decreased the exacerbation rate without increasing the dose of ICS or LABA in asthma. In this review, the mechanisms of action of LAMA in asthma were summarized and possible role of fixed dose ICS/LABA/ LAMA in asthma treatment was discussed under the light of current literature.
\end{abstract}

Key words: Inhaled cortikosteroid; long acting beta-2 agonist; long acting muscarinic antagonist; fixed dose ICS/LABA/LAMA; asthma

\section{GiRiş}

Astımın dünyanın değişik ülkelerindeki prevalansı \%1-20 arasında bildirilirken (1); ülkemizde erişkinlerdeki astım prevalansı \%1,2-9,4 arasında rapor edilmiştir (2). Astımın etkin tedavisi, hastaların hayat kalitesini artırmak ve ataklar nedeniyle hastane başvurularını azaltmak açısından büyük önem taşımaktadır (3).

Kırk yıldan uzun süredir inhale kortikosteroidler (IKS) astım tedavisinin yapı taşıdır. İnhale kortikosteroidlererin en etkili kontrol edici ilaç olduğu; semptom kontrolünü, hava yolu obstrüksiyonunu ve hava yolu aşırı duyarlılığını iyileştirdiği ve böylece astım ataklarını ve mortaliteyi azalttığı bilinmektedir (4). Düzenli iKS ve kIsa etkili beta-2 agonist ("short acting betaagonist", SABA) tedavisi ile kontrol sağlanamayan hastalarda IKS tedavisine uzun etkili beta-2 agonist, ("Long acting beta-2 agonist, LABA") eklenmesi astım basamak tedavisinde yerini almıştır (2). IKS/LABA sabit doz kombinasyonlarının uygulanan farklı dozlarda astım kontrolündeki etkinliklerinin yanı sıra sabit doz kombinasyon kullanılması ile ilaç uyumunun da arttığı çeşitli kontrollü çalışmalarda gösterilmiştir (5). Astımlı hastalarda parasempatik aktivite artmıştır ve bu durum hava yolu obstrüksiyonunun reverzibil olma potansiyeline sahip en önemli parçalarından birini oluşturur (6). IKS, LABA ve uzun etkili muskarinik antagonistler ("Long acting muscarinic antagonists, LAMA") arasındaki olumlu etkileşimlerine dair kanıtlar LAMA'nın astım tedavisinde kullanılmasını desteklemektedir (7). IKS/LABA kombinasyonuna tiotropiumun eklenmesiyle astım kontrolünde iyileşme sağlandığı gösterilmiştir (8).
Kronik obstrüktif akciğer hastalığı (KOAH)'nda LAMA tedavisinin semptomları baskıladığı, pulmoner rehabilitasyona katkısı olduğu, atak sayısını ve atağa bağlı hastaneye yatış sayısını azalttığı ortaya konmuştur. Atak oranını azaltmakta LAMA'ların LABA'lardan daha etkili olduğu bilinmektedir (9). KOAH tedavisinde LAMA'nın IKS/LABA kombinasyonuna eklenmesinin sonuçlarını inceleyen bir meta-analizde toplam 15,519 hastayı içeren 13 randomize kontrollü çalışma değerlendirilmiş; iKS/LABA/LAMA kombinasyonunun iKS/LABA'ya göre gerek $\mathrm{FEV}_{1}$ 'de düzelme oranında gerekse atak sayısının azaltmakta daha etkili olduğu gösterilmiştir (10).

Astımlı hastalarda IKS/LABA sabit doz kombinasyonunun hastaların tedavi uyumunu artırdığının gösterilmesi ve LAMA'ların bu kombinasyona eklenmesinin olumlu etkilerinin bildirilmesi astımlılarda da IKS/ LABA/LAMA sabit doz kombinasyonları üzerinde yoğun çalışmaların başlamasına neden olmuştur (1113). Bu derlemede IKS/LABA/LAMA sabit doz kombinasyonu ilaçların astım tedavisindeki potansiyel yeri klinik ve fonksiyonel parametreler eşliğinde gözden geçirilmiş̧tir.

\section{Astım Patogenezinde Kolinerjik Sistem}

Astım patogenezinde rol alan başlıca hücreler; eozinofiller, nötrofiller, lenfositler ve makrofajlardır. Bu hücrelerin yol açtığı kronik enflamasyon sonucunda geri dönüşümlü ve değiş̧ken hava yolu obstrüksiyonunu gelişir. Hem eozinofilik inflamasyonla gelişen Tip 2 astımda hem de non-eozinofilik enflamasyonla gelişen Tip 2 olmayan astımda gelişen hava yolu aşırı duyarlılığı sonucunda düz kas kontraksiyonu oluşur (14). Astımda vagus siniri tarafından kontrol edilen 
hava yolu tonusu artmıştır. M1 muskarinik reseptörler postsinaptik parasempatik ganglionlarda bulunurlar ve parasempatik iletiyi kolaylaştırırlar. M2 muskarinik asetilkolin reseptörü (mAChR) otoreseptör olarak işlev görür ve asetilkolin (ACh) salınımını inhibe eder. Hava yolu düz kas hücrelerinde lokalize olan M3 muskarinik ACh reseptörünün uyarılması ile fosfolipaz C (PLC)'yi aktive olur ve hücre içi $\mathrm{Ca}^{2+}$ konsantrasyonunu arttırarak hava yolu düz kas hücrelerinin kasılmasına neden olur. Hava yolları düz kasının ACh etkisiyle kasılması muskarinik M3 reseptörleri aracılığıyla olur (Şekil 1) (15).

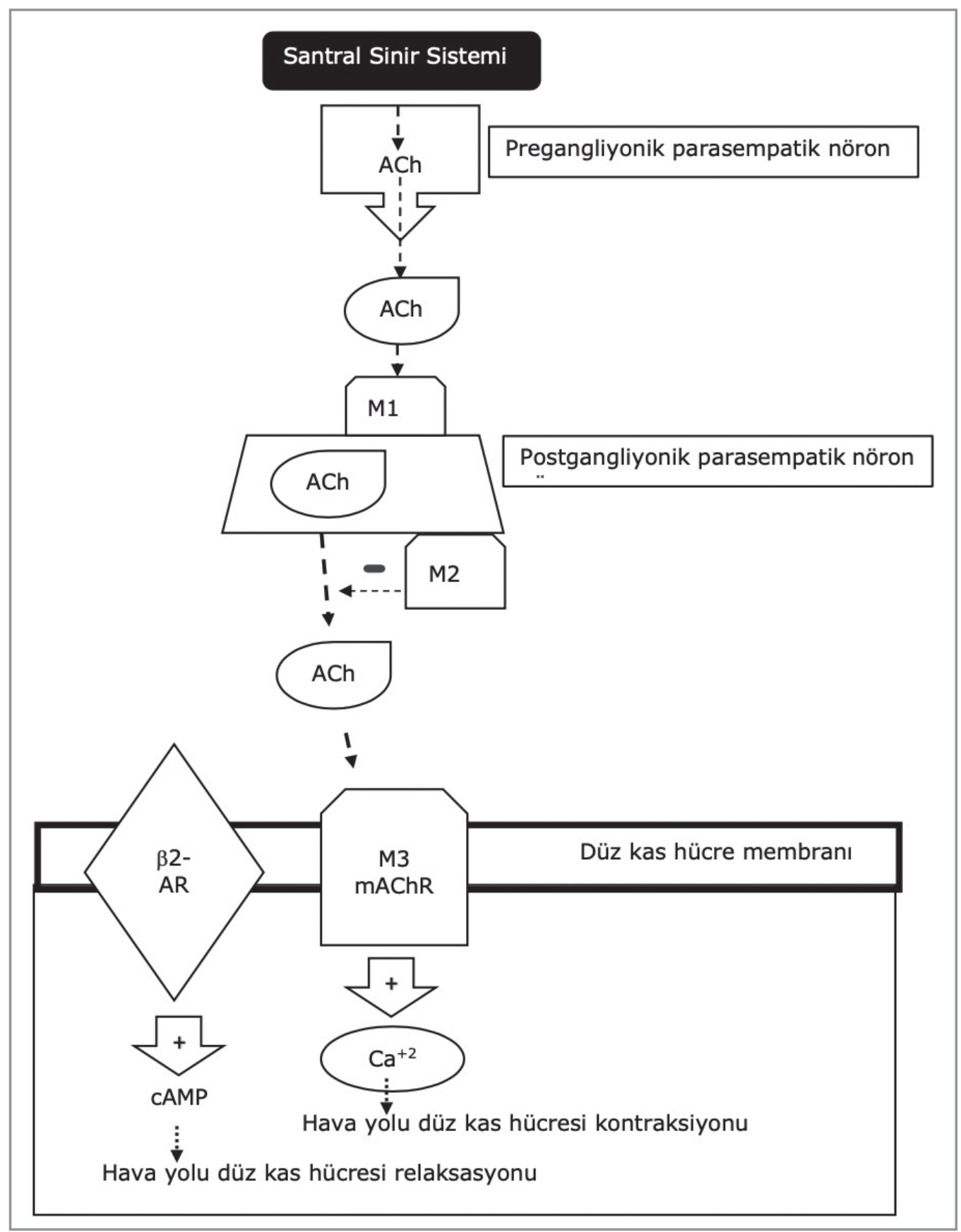

Şekil 1. Hava yolu düz kas hücresi ve parasempatik ileti.

$\beta 2$-AR: $\beta$-2 adrenoreseptör, ACH: Asetilkolin, M1: M1 muskarinik asetilkolin reseptörü, M2: M2 muskarinik asetilkolin reseptörü, M3: M3 muskarinik asetilkolin reseptörü, CAMP: Siklik adenozin monofosfat. 
Vagus siniri daha çok büyük hava yollarını innerve eder ve uyarıldığında havayolu düz kas hücrelerinde bulunan M3 reseptörlerini aktive eden ACh salgılanır. Küçük hava yollarında M3 reseptörleri hava yolu düz kas hücrelerinde bulunur ancak vagal sinirle uyarılmazlar. Nörojenik olmayan ACh hava yollarını kaplayan epitel hücrelerinden lokal olarak salınır (16).

Çevresel veya enfeksiyöz etkenlerin neden olduğu hava yolu enflamasyonu ve epitel hasarı duyusal sinir uçlarının açığa çıkmasına; duyu sinirlerinin uyarılması ise postgangliyonik ACh salınımına ve otoreseptör olan M2 mAChR işlevinin zayıflamasına neden olur (17). ACh salınmasıyla hava yolu düz kas tonusu artar. Bu durum hava yollarında kontraktiliteyi artırarak hava yollarında aşırı duyarlılığa neden olur (18). İmmünoglobulin E (IgE), otoreseptör olan M2 mAChR disfonksiyonuna yol açar. Bunun sonucunda kolinerjik sinirlerden ACh salınımının artmasıyla hava yolu kontraksiyonu artar (17).

M1 ve M3 mAChR'lerde artmış, M2 mAChR'lerde azalmış uyarı kolinerjik aktiviteyi artırır. Kolinerjik aktivitede artış ise bronş düz kasında kasılmaya, mukus sekresyonunda, enflamasyonda ve hava yolu yeniden yapılanmasında ("remodelling") arış̧a neden olur. Gerek nörojenik ve gerekse nörojenik olmayan ACh solunum yolunun inflamasyonuna ve remodelinge katkıda bulunur (19). Kolinerjik aktivasyona bağlı hava yolu düz kas kontraksiyonu mAChR antagonistleri tarafından azaltılır (15). Hem hayvan modellerinde hem de insanlarda gösterildiği gibi artmış kontraktil aktivite bronş aşırı duyarlılığına neden olur. Uzun etkili muskarinik antagonistler ACh sinyalini bloke eder. Bunun sonucunda kolinerjik aktivitenin azalması düz kas kontraktilitesinde ve hava yolu aşırı duyarlıı̆̆ında azalmaya yol açar (17).

\section{Hava Yolunda Beta Reseptör ve Muskarinik Reseptör ilişsisi}

Hava yolu düz kas hücrelerindeki M3 mAChR'lerin Ach ile uyarılması sonucunda fosfolipaz C (PLC) aktive olur ve hücre içi $\mathrm{Ca}^{++}$konsantrasyonu artar. Bunun sonucunda da düz kas kontraksiyonu gelişir.

Beta-2 reseptörlerin adrenerjik uyarımının sonucunda hava yolu düz kas hücrelerinde hücre membranında adenil siklaz (AC) aktivasyonu olur ve hücre içi siklik adenozin monofosfat (CAMP) artar. Bunun sonucunda cAMP'ye bağlı protein kinaz A'nın aktivasyonu gerçekleşir. Protein kinaz A hava yolu düz kas tonusunun kontrolünde yer alan önemli düzenle- yici proteinleri fosforile eder. Hücre içindeki kalsiyum $\left(\mathrm{Ca}^{2+}\right)$ un dışarıya atılması ve intraselüler depolara taşınması hava yolu düz kas gevşemesiyle sonuçlanır (20). Kalsiyumla aktive olan potasyum $\left(\mathrm{KCa}^{2+}\right)$ kanal aktivasyonu sonucunda hava yolu düz kas gevşemesi olduğu gösterilmiştir. Protein tirozin kinazlar ve $\mathrm{KCa}^{++}$kanallarının da son zamanlarda LABA'lar ve LAMA'lar arasındaki sinerjistik etkileşiminde önemli olduğu gösterilmiştir (15).

Ayrıca M3 reseptör aktivasyonu Protein kinaz $C^{\prime} y i$ (PKC) aktive ederek beta-2 adrenoreseptör ve Gs birimindeki proteinleri fosforile eder. Fosforilazasyon sonucunda bu proteinlerde desensitizasyon meydana gelir. Bu da ( $\beta 2-\mathrm{AR})$ aracılı hava yolu düz kas gevşemesini olumsuz etkiler. Hava yolu düz kas hücrelerinde M3 muskarinik reseptörlerin inhibisyonu, asetilkolinin neden olduğu kontratil cevabı önler ve LABA'lar tarafından indüklenen bronkodilatasyonu güçlendirir (21).

\section{Astım Tedavisinde Antikolinerjikler}

Astım tedavisinde kullanılan ilaçları; kontrol edici, semptom giderici ve ilave tedaviler olmak üzere gruplandırabiliriz. IKS ve lökotrien reseptör antagonisleri gibi ilaçlar antienflamatuvar etkileri sayesinde astımın kontrol altında tutulmasını sağlar. Semptom giderici ilaçlar ise kısa etkili SABA, ipratropium gibi kısa etkili inhale muskarinik antagonistler (SAMA), düşük doz iKS ve formoterol sabit doz kombinasyonu, IKS ve/veya sistemik kortikosteroid, magnezyum sülfat ve kısa etkili teofilindir. Yüksek doz kontrol edici tedaviye ve risk faktörlerinin kontrol edilmesine rağmen astımı kontrol altında olmayan ve sık atak öyküsü olan hastalarda "ek tedaviler" gerekebilir. Başlıca ek ilaçlar; makrolidler, yavaş salınımlı teofilin, uzun süreli düşük doz oral steroid (OKS) biyolojik ajanlar ve LAMA (tiotropium)'dır $(2,22,23)$. Ülkemizde bulunan, farklı etki süreleri olan LAMA' lar ve bunların ve IKS/LABA ile sabit kombinasyonları Tablo 1'de özetlenmiştir.

\section{a- Kısa etkili inhale muskarinik antagonistler}

Datura stramonyum bitkisinin yanmasıyla oluşan dumanın 1800'lerin başından itibaren obstrüktif hava yolu hastalığı tedavisinde kullanılmasıyla mAChR antagonistlerin etkinliği bilinir hale gelmiştir (24). Ardından atropin ile klinik çalışmalar yürütülmüş ve atropinin yerini daha iyi etkinlik ve daha az sistemik etkileri nedeniyle ipratropium bromür almıştır. $\mathrm{KOAH}$ için kolinerjik (vagal) tonusun hastalığın tek 
Tablo 1. Ülkemizde bulunan uzun etkili muskarinik antagonistler (LAMA) ve iKS/LABA/LAMA fiks kombinasyonlarının dozları, kullanım sıklıkları ve kullanım onayı aldığı endikasyonlar

\begin{tabular}{|lcc|}
\hline Etken madde(ler) & Doz ve kullanım sıklı̆̆ı & Kullanım onayı aldığı endikasyonlar \\
\hline LAMA & & KOAH \\
Tiotropium bromür & $18 \mu \mathrm{g}, 1 \times 1$ & $\mathrm{KOAH}$ \\
Glikopronyum & $50 \mu \mathrm{g}, 1 \times 1$ & $\mathrm{KOAH}$ \\
LABA/LAMA fiks kombinasyonu & & $\mathrm{KOAH}$ \\
Vilanterol/Umeklidinyum Bromur & $25 / 62.5 \mu \mathrm{g}, 1 \times 1$ & $\mathrm{KOAH}$ \\
IKS/LABA/LAMA fiks kombinasyonlar & & $100 / 6 / 12.5 \mu \mathrm{g}, 2 \times 1$ \\
Beklometazon/Formoterol/ Glikopronyum & $100 / 25 / 62.5 \mu \mathrm{g}, 1 \times 1$ & \\
Flutikazon/Vilanterol/Umeklidinyum/ & & \\
\hline LABA: Uzun etkili beta-2 agonist, iKS: İnhale kortikosteoid, LAMA: Uzun etkili muskarinik antagonist, KOAH: Kronik obstrüktif akciğer hastalığı. \\
\hline
\end{tabular}

geri dönüşümlü bileşeni olduğuna inanıldığı için $\mathrm{mAChR}$ antagonistlerinin sadece $\mathrm{KOAH}$ tedavisinde etkili olduğu ve astım tedavisinde yeri olmadığı düşünülmüştür. Astımda gelişen bronkokonstrüksiyonda enflamatuvar mediyatörlerin ve lökotrienlerin etkisinin kolinerjik komponentten daha güçlü olduğunun kabul edilmesi nedeniyle mAChR antagonistlerinin bronkodilatörler olarak $\beta 2$-agonistlere göre daha az etkili olduğu kabul edilmiştir (7). Astım ataklarında ise daha yavaş bir etki başlangıcı nedeniyle SAMA'lar semptom giderici ilaçlar olarak ikinci seçenek haline gelmiştir (23).

\section{b- Uzun etkili inhale muskarinik antagonistler}

Kolinerjik uyarılar vagal tonusun günlük varyasyonuna önemli oranda katkıda bulunur. Özellikle gece semptomu olan astım hastalarında muskarinik antagonistler ile kolinerjik tonusun azaltılabileceği bilinmektedir. Son 20 yıl içinde yapılan çalışmalarda tiotropiumun ve glikopironyumun hafif atopik astımı olan hastalarda solunum fonksiyonunu iyileştirdiği ve metakolinin neden olduğu bronkokonstrüksiyona karşı koruduğu gösterilmiştir (7). Astımlı hastalarda iKS'ye LAMA (tiotropium) veya LABA (salmeterol) eklenmesinin etkinliğini değerlendiren dört randomize kontrollü çalışmanın meta-analizinde LABA'ların yaşam kalitesimi artırma açısından LAMA'lara göre avantajlı olduğu bildirilmiştir (25).

Yapılan deneysel hayvan çalışmalarında tiotropiumun, metakolinin neden olduğu bronkospazmı inhibe ettiği ve inhalan alerjene geç yanıtta mAChR antagonistlerinin önemli bir rol oynadığını sonucuna varılmıştır. Bu bulguların yanı sıra tiotropiumun hava yollarında eozinofilik enflamasyonu ve vagotomize hayvanlar da dahil olmak üzere antijenle indüklenen hava yolu aşırı duyarlılığını inhibe ettiği gösterilmiştir (17). Bu çalışmalar uzun etkili muskarinik antagonizmanın astımlı hastalarda potansiyel klinik fayda sağlayabileceğine dair kanıtlar sağlamıştır.

Son yıllarda astımlı hastalarda IKS ve LABA kombinasyonu ile optimal tedaviye rağmen semptom kontrolü sağlanamayan veya alevlenmeleri olan hastalarda ilk olarak tiotripiyumun tedaviye eklenmesinin Tip 2 fenotipinden bağımsız olarak akciğer fonksiyonlarında düzelmeyi sağladığı ve sistemik steroid tedavisi gerektiren atakları geciktirdiği gösterilmiştir (8, 26,27). Bunun sonucu olarak "Global Initiative for Asthma (GINA)", "European Respiratory Society $(E R S)$ " ve "American Respiratory Society (ARS)" tarafından astım tedavisi konusunda hazırlanan güncel rehberlerde tiotropiumun biyolojik ilaçlar veya OKS'den önce tedaviye eklenmesi önerilmektedir $(23,28)$.

\section{c- Sabit doz kombine LAMA/LABA ve IKS/LAMA}

Uzun etkili muskarinik antagonistlerin bir LABA ile birlikte uygulanması, cAMP sentezini artırarak hava yolu düz kaslarının gevşemesine neden olur. Son zamanlarda protein tirozin kinazlar ve $\mathrm{KCa}^{2+}$ kanallarının da LABA'lar ve LAMA'lar arasındaki sinerjistik etkileşimde önemli olduğu gösterilmiştir. Küçük hava yollarında hava yolu düz kaslarının tonusunun modülasyonu, epitelde sentezlenen ve salınan nörojenik olmayan ACh'nin kontrolü altındadır. LABA'lar ve LAMA'lar bronşiyal epitel hücrelerinin yüzeyinde bulunan M3 mAChR'leri antagonize eder. Bu da organik katyonik taşıyıcı aktiviteyi modüle ederek nörojenik olmayan ACh salınımının azalmasına yol açar. Bu kombinasyonun sağladığı sinerjiden $\mathrm{KOAH}$ tedavisinde oldukça sık faydalanılır. Sensitize edilmiş 
hava yolu düz kaslarına beklometazon ve glikopronyum uygulandığında sinerjik etki ile cAMP konsantrasyonunun artırgı ve bronşlarda/ bronşiyollerde düz kas tonusunun azalttığı gösterilmiştir (29).

LABA'lar ve LAMA'lar bronşiyal tonusu farklı mekanizmalar ile etkiler. Hava yolu düz kas hücrelerinde kontraktilite inhibisyonuna ek olarak $\mathrm{KCa}^{2+}$ kanallarının aktivitesi, tirozin kinaz proteinleri ve nöronal olmayan ACh'nin epitel salımı gibi birçok mekanizma ile bronşiyal tonusu etkilerler (30).

In vitro kortikosteroid tedavisi hava yolu düz kasında ACh'ye duyarlılığı azaltır. Otoreseptör olan M2, mAChR seviyelerini artırır. ACh salınımını azaltmasının yanı sıra ACh'nin kolinesterazlar tarafından yıkımını artırır. Beklametazon ve glikopronium arasındaki sinerjik etkileşim artmış cAMP konsanstrasyonu ile ilişkili bulunmuştur. Histamin ile pasif olarak sensitize edilmiş hava yolu düz kasına beklametazon ve glikopronium uygulanmasıyla belirgin relaksasyon geliştiği görülmüştür (29).

\section{d- Sabit doz kombine iKS/LABA/LAMA}

Günümüzde IKS'lere LABA ve LAMA eklenerek oluşturulan sabit doz kombinasyonlar ile etkin bronkodilatasyon sağlanabileceğini gösterilmiştir. Bu kombinasyonların kullanımının herhangi bir etken maddenin dozunu artırmaya gerek kalmadan astım hastalarına solunum fonksiyonlarında iyileşme ve atak sıklığında azalma sağladı̆̆ı gösterilmiştir (7).

Deneysel bir çalışmada akciğer kanseri nedeniyle lobektomi yapılan hastaların operasyon materyallerindeki sağlıklı alanlar alınarak astım modeli, stabil $\mathrm{KOAH}$ modeli ve kontrol grubu oluşturulmuştur. Bu bronş dokuları histamin ve karbakol ile uyarılarak kontrakte edilmiş̧ir. Ardından beklametazon, formeterol ve glikopironyum ile hem tek tek hem de üçlü kombinasyon olarak hava yollarının yanıtı değerlendirilmiştir. Üçlü kombinasyon farklı dozlarda uygulanmış ve en yüksek orandaki sinerjistik bronkodilatatör etki beklametazon, formeterol ve glikopironyumun 100:6:12,5 ng. $\mathrm{ml}^{-1}$ dozunda uygulandığı grupta saptanmıştır (31).

Tek bir inhalerde IKS/LABA/LAMA dan oluşan üçlü kombinasyonun IKS/LABA kombinasyonu ile etkinliğinin karşılaştırıldığı ilk faz 3 çalışmalardan TRIGGER çalışması 17 ülkeden 221 merkezden 1447 astımlı hastanın katılımı ile, TRIMARAN çalışması ise 16 ülkeden 171 merkezden 1155 erişkin astımlı hastanın katılımı ile gerçekleştirilmiştir (11). Son bir yıl içinde en az bir kez astım atağı geçiren ve IKS/LABA ile astımı kontrol edilemeyen hastaların dahil edildiğ randomize kontrollü bu çalışmalarda IKS olarak beklometazon dipropiyonat (BDP), LABA olarak formoterol fumarat (FF) ve LAMA olarak glikopironyumun (G) kombinasyonu kullanılmış ve sonuçlar ile BDP/FF inhaler kombinasyonu karşılaştırılmıştır. TRIMARAN grubundaki ilaç kombinasyonları orta doz IKS içerirken TRIGGER grubundaki ilaç kombinasyonları ise yüksek doz iKS içerecek şekilde düzenlenmiştir. TRIMARAN çalışmasında hastalar BDP/FF/G (100 $\mu \mathrm{g}$ BDP, $6 \mu \mathrm{g}$ FF ve $10 \mu \mathrm{g}$ G) veya BDP/FF (100 $\mu \mathrm{g}$ BDP ve $6 \mu \mathrm{g}$ FF) günde iki kez iki inhalasyon alacak şekilde randomize edilmiştir. TRIGGER çalışmasında ise hastalar BDP/FF/G (200 $\mu$ g BDP, $6 \mu \mathrm{g}$ FF ve $10 \mu \mathrm{g}$ G) veya BDP/FF (200 BDP ve 6 g FF) günde iki kez iki inhalasyon kullanacak şekilde randomize edilirken; bir grup hastada açık etiketli olarak BDP/FF (200 $\mu$ g BDP ve $6 \mu \mathrm{g} F$ ) günde iki kez iki inhalasyon ve günde bir kez tiotropium 2,5 $\mu \mathrm{g}$ iki inhalasyon kullanacak şekilde randomize edilmişlerdir. Hastaların 26. haftada yapılan değerlendirmesinde her iki çalışmada da $\mathrm{BDP} / \mathrm{FF} / \mathrm{G}$ kullanan hastalarda $\mathrm{FEV}_{1}$ değerindeki iyileşme BDP/FF kullananlardan istatistiksel daha yüksek bulunmuştur. TRIGGER çalışmasında 52 haftalık izlemde orta ve ağır atakların görülme sıklığındaki azalma BDP/FF/G kullanan hastalarda $\% 15(p=0,11)$; TRIMARAN çalışmasında ise $\% 12(p=0,033)$ olarak bildirilmiştir (Tablo 2). Toplamda her iki çalışmada BDP/FF/G kullanan hastalardan beşi BDP/FF kullanan hastalardan ise biri hayatını kaybetmiş. Ölümlerin hiçbiri tedaviyle ilgili bulunmamıştır.

TRIGGER ve TRIMARAN çalışmalarına katılan hastalarda BDP/FF/G ile BDP/FF etkinliğinin mevsimlere göre karşılaştırıldığı ek analizde; tedaviye LAMA eklenen hasta grubunda sadece IKS/LABA alan hastalara göre kış aylarında atak oranının \%20,3 azaldığı $(p=0,008)$ diğer mevsimlerde ise atak oranındaki azalmanın \%8,6 ile \%12,8 arasında olduğu belirlenmiştir (32).

Son bir yıl içinde en az bir astım atağı geçiren, orta veya yüksek doz iKS/LABA ile semptomları kontrol edilmeyen ve $\mathrm{FEV}_{1} \% 80$ 'in altında olan 18 ile 75 yaş arası 3092 hastanın katıldığı bir diğer randomize kontrollü çalışmada (IRIDIUM) günde tek doz inhale mometazon furoat, indakaterol asetat ve glikopironyum bromürün (MF/IND/GLY) kombinasyonunun iKS/LABA'ya karşı etkinliği ve güvenliği araştırılmıştır (12). Orta ve yüksek MF/IND/GLY dozları (sırasıyla $80 / 150 / 50$ ve $160 / 150 / 50 \mu \mathrm{g}$ ), orta ve yüksek MF/ 
Tablo 2. TRIMARAN ve TRIGGER faz 3 çalışması

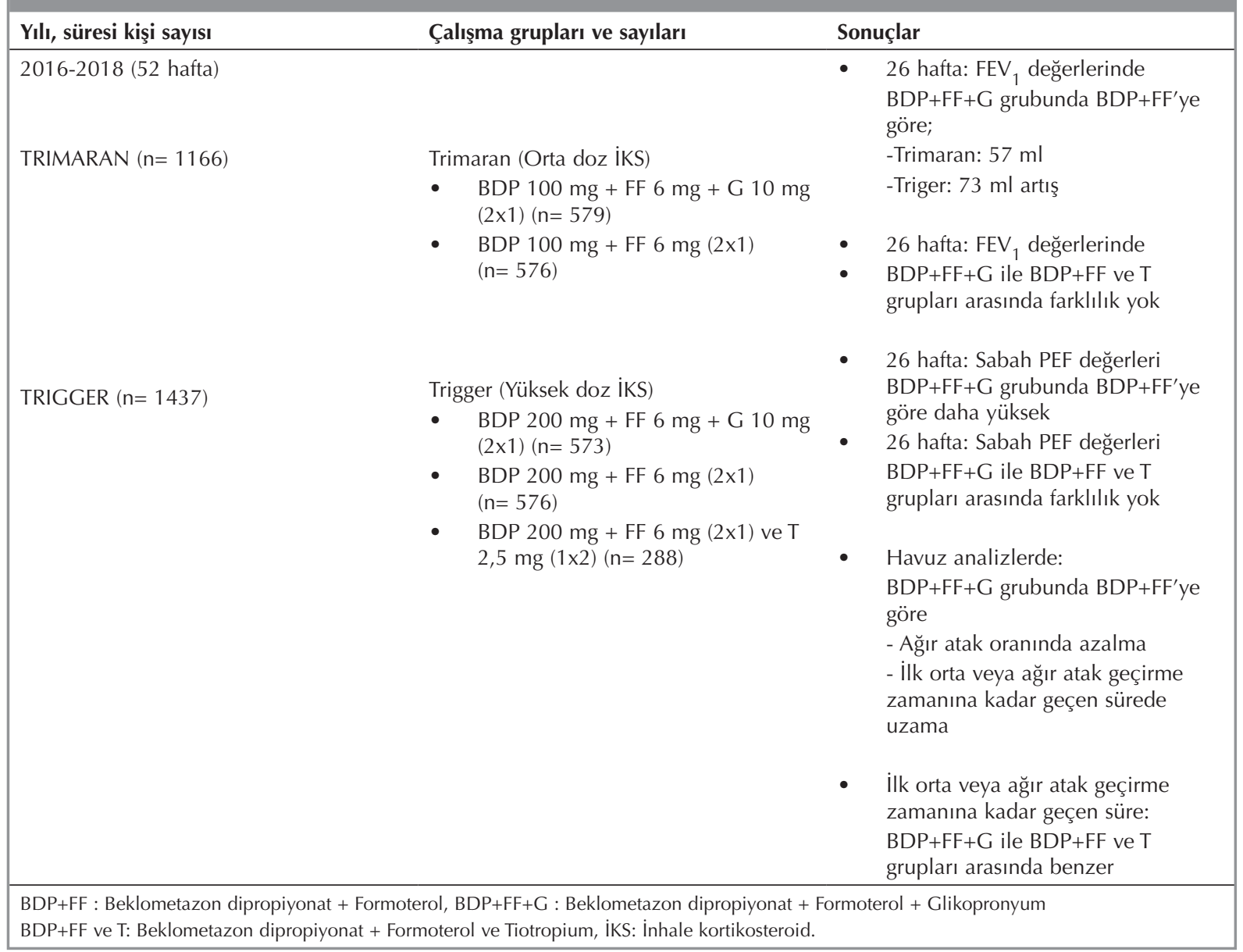

IND dozlarıyla (sırasıyla 160/150 $\mu \mathrm{g}$ ve 320/150 $\mu \mathrm{g}$ ) veya yüksek doz flutikazon ve salmeterol (FLU/SAL,

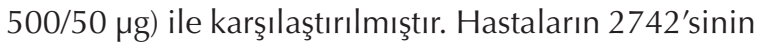
52 haftalık izlemi tamamladığı çalışmada 26. haftada $\mathrm{FEV}_{1}{ }^{\prime}$ deki düzelme orta doz MF/IND/GLY ve yüksek doz MF/IND/GLY kombinasyonlarında MF/IND'ye göre istatistiksel olarak anlamlı olarak yüksek bulunmuştur. $\mathrm{FEV}_{1}$ 'in plato düzeyindeki düzelme hem yüksek hem de orta doz MF/IND/GLY kombinasyonu ile yüksek doz FLU/SAL kombinasyonundan daha iyi bulunmuştur $(p<0,001)$ (Tablo 3). Yüksek doz MF/ IND kullanan hastalardan dördü, yüksek doz MF/ IND/GLY kullanan hastalardan ikisi ve orta doz MF/ IND/GLY kullanan hastalardan birinin hayatını kaybettiği çalışmada ölümlerden hiçbiri çalışmayla ilişkili bulunmamıştır. Tedavide kullanılan kombinasyonların yan etki profilleri birbirine benzer bulunmuştur.
Kontrolsüz astımı olan hastalarda yapılan bir başka Faz 3 çalışması olan ARGON çalışmasında ise yüksek doz MF/IND/GLY günde tek sefer inhale kullanımının günde iki kez yüksek doz FLU/SAL'a tek doz tiotropium eklenmesine göre astım kontrolünü sağlamakta daha başarılı olduğu; orta doz MF/IND/GLY sabit inhalerin ise günde iki kez yüksek doz FLU/ SAL'a tek doz tiotropium eklenmesiyle benzer etkinliğe sahip olduğu gösterilmiştir (33).

TRIMARAN ve TRIGGER çalışmalarında glikopironyum günde iki kez uygulanırken, IRIDIUM çalışmasındaki MF/IND/GLY üçlü kombinasyonu günde tek sefer fakat daha yüksek dozda kullanılmıştır $(11,12)$. Günde bir kez uygulamanın hastaların tedavi uyumu açısından bir avantaj oluşturacağı düşünülmekle beraber bu parametre çalışmalarda ayrıntılı olarak incelenmemiştir. IRIDIUM çalışmasında üçlü tedavinin hangi hasta gruplarında daha etkin olacağını 


\section{Tablo 3. IRIDIUM faz 3 çalışması}

\begin{tabular}{|c|c|c|}
\hline Yılı, süresi kişi sayısı & Çalışma grupları ve sayıları & Sonuçlar \\
\hline $\begin{array}{l}2015-2019 \\
(52 \text { hafta) } \\
n=3092\end{array}$ & 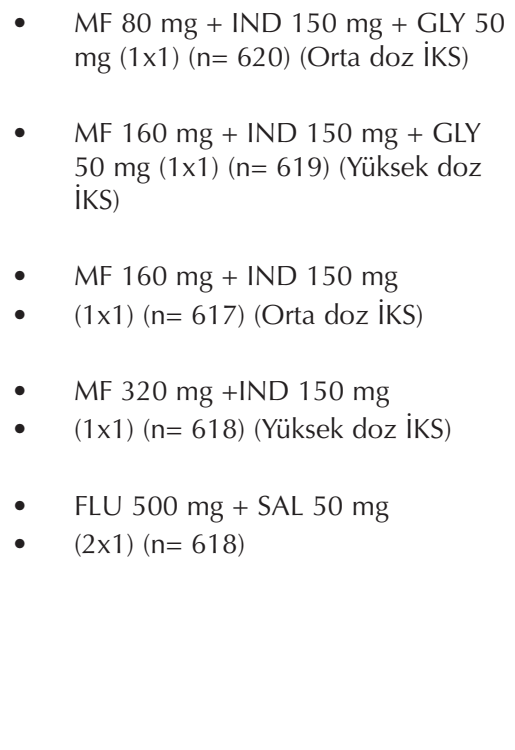 & $\begin{array}{l}\text { - } 26 \text { hafta: } F_{1} \text { değerlerinde } \\
\text { Orta ve Yüksek doz MF+IND } \\
\text { tedavisine GLY eklenmesiyle orta ve } \\
\text { yüksek doz MF+IND ve yüksek doz } \\
\text { FLU+SAL'a göre daha belirgin } \\
\text { iyileşme } \\
52 \text { hafta: } \\
\text { ACQ-7'de gruplar arası anlamlı } \\
\text { değişiklik yok } \\
52 \text { hafta: } \\
\text { Yıllık orta -ağır atak oranı orta ve } \\
\text { yüksek doz IKS içeren MF+IND'ye } \\
\text { göre; } \\
\text { Yüksek doz IKS içeren } \\
\text { MF+IND+GLY ile \%15 } \\
\text { Orta doz IKS içeren } \\
\text { MF+IND+GLY ile \%13 azalma } \\
52 \text { hafta: } \\
\text { Ataklarda azalma orta ve yüksek } \\
\text { doz MF+IND+GLY'de yüksek doz } \\
\text { FLU+SAL'a göre daha fazla }\end{array}$ \\
\hline
\end{tabular}

belirlemek amaçlı yapılan alt analizlerde anlamlı bir farklılık saptanamamıştır (12). Yine bu çalışmada $\beta 2$-adrenoseptör agonistler ile değişkenlik konusunda bir bilgi yer almamaktadır (34).

On beş ülkeden 415 merkezde izlenen 18 yaş üstü 2439 hastanın dahil edildiği randomize CAPTAIN çalışmasında; IKS/LABA tedavisi altında astımı kontrole alınamayan (bronkodilatör öncesi $\mathrm{FEV}_{1}$ değeri öngörülen normal değerin \%30 ile \%85'i arasında ve değişkenliğin olduğu) hastalarda flutikazon furoat, umeklidinyum ve vilanterol (FF/UMEC/NI) ile FF/VI karşılaştırılmıştır (13). Araştırma ilaçlarının tümünün çok dozlu kuru toz inhaler kullanılarak verildiği çalışmada üçlü tedavi, 24. haftada $\mathrm{FEV}_{1}$ üzerinde başlangıca göre daha büyük etkiler gösterirken, astım atak oranları arasında anlamlı bir fark saptanmamıştır. Tüm FF kullanan gruplar bir arada incelendiğinde kan eozinofil sayımları ve ekshale nitrik oksit (NO) ölçümleri ile daha şiddetli Tip 2 hava yolu enflamasyonu olan hastalarda yüksek doz IKS'nin orta veya ağır şiddette astım atağını önlemede düşük dozdan daha etkili olduğu görülmüştür (Tablo 4).

Toplamda 9535 hastanın dahil edildiği bu beş çalışmanın meta-analizinde yüksek doz iKS içeren sabit doz IKS/LABA/LAMA terapileri, orta doz IKS/LABA/
LAMA sabit doz uygulamalarından ve hem yüksek hem de orta doz IKS/LABA sabit doz uygulamalarından orta veya ağır astım ataklarını azaltmakta daha etkili $(p<0,05)$ bulunmuştur. Bunun yanı sıra FEV değeri bu tedaviyi alan hastalarda belirgin olarak yükselmiştir (33 ml'den +114 ml'ye). Yüksek doz IKS içeren sabit doz üçlü kombinasyon terapileri ağır astım ataklarını önlemekte orta doz IKS/LABA/LAMA daha üstün $(p<0,05)$ bulunurken, orta şiddetteki astım ataklarını önlemede her iki grup arasında istatistiksel olarak anlamlı bir fark bulunmamıştır (35).

Sonuç olarak, IKS/LABA kombinasyonu ile kontrol altında olmayan astımlılarda tedaviye LAMA eklenmesinin güvenli ve etkili olduğunu gösteren randomize kontrollü ve çok sayıda hasta üzerinde yapılmış çalışmalar yayınlanmıştır. Bu çalışmalarda IKS/LABA/ LAMA kombinasyonlarının astımlı hastalarda $\mathrm{FEV}_{1}$ değerlerinde artış, ağır atak oranında azalma ve ilk orta-ağır atak geçirme zamanında uzama gösterilmiştir. Bu çalışma sonuçları son GINA rehberlerinde ağır astımı olan hastalar için biyolojik ajan veya OKS tedavisi başlatılmadan önce yüksek doz IKS/LABA ya tiotropium eklenmesi şeklinde bir değişikliğe neden olmuştur. Sabit doz IKS/LABA/LAMA kombinasyonlarından flutikazon furoat/umeklidinyum/vilanterol kombinasyonu Eylül 2020'de "Food and Drug 


\begin{tabular}{|c|c|c|}
\hline Yılı, süresi kişi sayısı & Çalışma grupları ve sayıları & Sonuçlar \\
\hline $\begin{array}{l}2016-2018(24-52 \text { hafta }) \\
n=2436\end{array}$ & 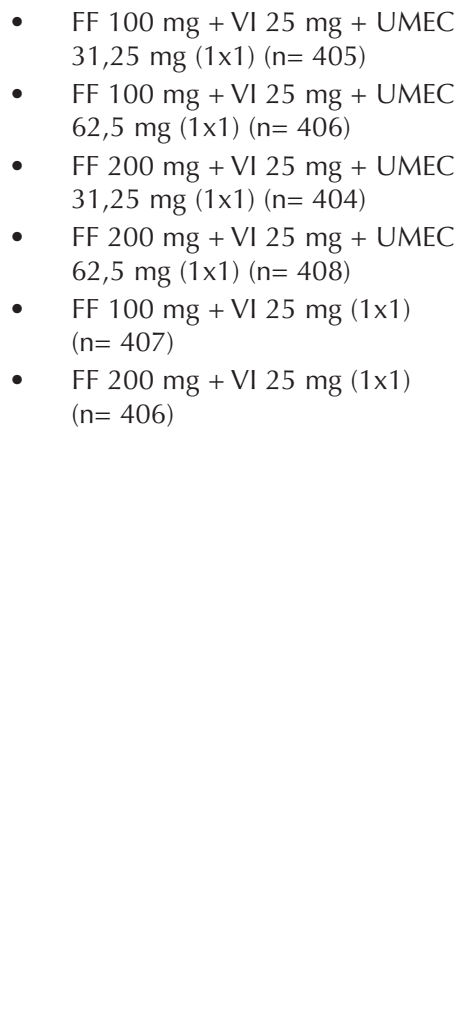 & 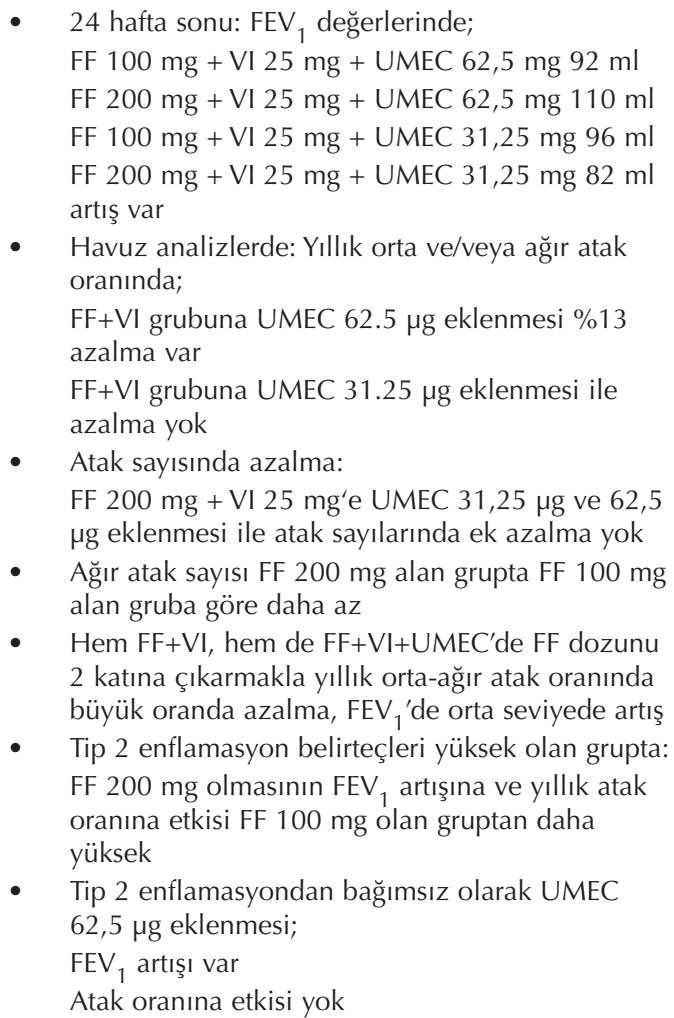 \\
\hline
\end{tabular}

Administration (FDA)" astımda kullanımı konusunda onay almıştır (36). Aynı kombinasyonun astımda kullanımı için yapılan başvuru 25 Şubat 2021'de "European Medicines Agency (EMA)" tarafından reddedilmiştir (37). Bu sonuçlar henüz uluslararası ve ulusal astım rehberlerinde herhangi bir değişikliğe neden olmamış ve son astım rehberlerinde henüz bu üçlü kombinasyon tedavi basamaklarında yer almamıştır. Ayrıca bu ilaçların hangi klinik ve biyolojik özelliklere (fenotiplere) sahip astım hastalarında daha etkili olduğunun belirlenmesi konusunda ileri çalışmalara ihtiyaç vardır. Tüm bu noktalar önümüzdeki yıllarda açığa kavuştuğunda sabit doz iKS/LABA/ LABA kombinasyonlarının günlük pratiğimizde nasıl kullanılır olacağı kesinlik kazanacaktır.

\section{KAYNAKLAR}

1. Aaron SD, Boulet LP, Reddel HK, Gershon AS. Underdiagnosis and overdiagnosis of asthma. Am / Respir Crit Care Med 2018; 198(8): 1012-20.
2. Astım Tanı ve Tedavi Rehberi 2020 Güncellemesi. GE Çelik (ed). Available from: https://www.aid.org.tr/ wp-content/uploads/2020/12/astim-rehberi-2020.pdf

3. Hossny E, Caraballo L, Casale T, El-Gamal Y, Rosenwasser L. Severe asthma and quality of life. World Allergy Organ J 2017; 10(1): 28.

4. Cusack RP, Satia I, O'Byrne PM. Asthma maintenance and reliever therapy: Should this be the standard of care? Ann Allergy Asthma Immunol 2020; 125(2): 150-5.

5. Scichilone N, Rossi A, Melani A. Revising old principles of inhaled treatment in new fixed combinations for asthma. Pulm Pharmacol Ther 2015; 33: 32-8.

6. Matera MG, Cazzola M. Muscarinic receptor antagonists. Handb Exp Pharmacol 2017; 237: 41-62.

7. Papi A, Fabbri LM, Kerstjens HAM, Rogliani P, Watz H, Singh $D$. Inhaled long-acting muscarinic antagonists in asthma- a narrative review. Eur J Intern Med 2021; 85: 14-22.

8. Kerstjens HAM, Engel M, Dahl R, Paggiaro P, Beck E, Vandewalker $M$, et al. Tiotropium in asthma poorly controlled with standard combination therapy. N Engl I Med 2012; 367(13): 1198-207. 
9. Global Initiative for Chronic Obstructive Lung Disease (GOLD 2021). Available from: https://goldcopd.org/ wp-content/uploads/2020/11/GOLD-REPORT-2021v1.1-25Nov20_WMV.pdf

10. Calzetta L, Cazzola M, Matera MG, Rogliani P. Adding a LAMA to ICS/LABA therapy: a meta-analysis of triple combination therapy in COPD. Chest 2019; 155(4): 758-70.

11. Virchow IC, Kuna P, Paggiaro P, Papi A, Singh D, Corre $S$, et al. Single inhaler extrafine triple therapy in uncontrolled asthma (TRIMARAN and TRIGGER): two double-blind, parallel-group, randomised, controlled phase 3 trials. Lancet 2019; 394(10210): 1737-49.

12. Kerstjens HAM, Maspero J, Chapman KR, van Zyl-Smit $R N$, Hosoe $M$, Tanase A-M, et al. Once-daily, single-inhaler mometasone-indacaterol-glycopyrronium versus mometasone-indacaterol or twice-daily fluticasone-salmeterol in patients with inadequately controlled asthma (IRIDIUM): a randomised, double-blind, controlled phase 3 study. Lancet Respir Med 2020; 8(10): 1000-12.

13. Lee LA, Bailes Z, Barnes N, Boulet L-P, Edwards D, Fowler $A$, et al. Efficacy and safety of once-daily single-inhaler triple therapy (FF/UMEC/VI) versus FF/VI in patients with inadequately controlled asthma (CAPTAIN): a doubleblind, randomised, phase 3A trial. Lancet Respir Med 2021; 9(1): 69-84.

14. Mark L. Pathogenesis of asthma. Bruce S Bochner (ed). Available from: www.uptodate.com/an (2021).

15. Matera MG, Page CP, Calzetta L, Rogliani P, Cazzola M. Pharmacology and therapeutics of bronchodilators revisited. Pharmacol Rev 2020; 72(1): 218-52.

16. Barnes PJ. Severe asthma: advances in current management and future therapy. I Allergy Clin Immunol 2012; 129(1): 48-59.

17. Cazzola M, Puxeddu E, Matera MG, Rogliani P. A potential role of triple therapy for asthma patients. Expert Rev Respir Med 2019; 13(11): 1079-85.

18. Boss'e Y, Chin LYM, Par'e PD, Seow CY. Adaptation of airway smooth muscle to basal tone relevance to airway hyperresponsiveness. Am J Respir Cell Mol Biol 2009; 40(1): 13-8.

19. Matera MG, Rinaldi B, Berardo C, Rinaldi M, Cazzola M. A review of the pharmacokinetics of M3 muscarinic receptor antagonists used for the treatment of asthma. Expert Opin Drug Metab Toxicol 2020; 16(2): 143-8.

20. Billington CK, Hall IP. Novel CAMP signalling paradigms: therapeutic implications for airway disease. Br J Pharmacol 2012; 166(2): 401-10.

21. Calzetta L, Matera MG, Cazzola M. Pharmacological interaction between $\angle A B A s$ and $L A M A s$ in the airways: optimizing synergy. Eur J Pharmacol 2015; 761: 168-73.

22. Global Initiative for Asthma (GINA). Global strategy for asthma management and prevention. Global strategy for asthma management and prevention. Available from: https://ginasthma.org/wp-content/uploads/2019/06/ GINA-2019-main-report-June-2019-wms.pdf
23. Global Initiative for Asthma (GINA). Global strategy for asthma management and prevention. Global strategy for asthma management and prevention, Global Initiative for Asthma (GINA) 2020. Available from: https://ginasthma. org/wp-content/uploads/2020/06/GINA-2020report_20_06_04-1-wms.pdf

24. Mansfield L, Bernstein JA. Tiotropium in asthma: From bench to bedside. Respir Med 2019; 154: 47-55.

25. Kew KM, Evans DJ, Allison DE, Boyter AC. Long-acting muscarinic antagonists (LAMA) added to inhaled corticosteroids (ICS) versus addition of long-acting beta2-agonists (LABA) for adults with asthma. Cochrane Database Syst Rev 2015; 2015(6): CD011438.

26. Kerstjens HA, Casale TB, Bleecker ER, Meltzer EO, Pizzichini E, Schmidt O, et al. Tiotropium or salmeterol as add-on therapy to inhaled corticosteroids for patients with moderate symptomatic asthma: two replicate, doubleblind, placebo-controlled, parallel-group, active-comparator, randomised trials. Lancet Respir Med 2015; 3(5): 367-76.

27. Casale TB, Bateman ED, Vandewalker $M$, Virchow $J C$, Schmidt $H$, Engel $M$, et al. Tiotropium respimat add-on is efficacious in symptomatic asthma, independent of $T 2$ Phenotype. J Allergy Clin Immunol Pract 2018; 6(3): 92335.

28. Holguin F, Cardet JC, Chung KF, Diver S, Ferreira DS, Fitzpatrick $A$, et al. Management of severe asthma: a European Respiratory Society/American Thoracic Society guideline. Eur Respir J 2020; 55(1): 1900588.

29. Cazzola M, Calzetta L, Rogliani P, Puxeddu E, Facciolo F, Matera MG. Interaction between corticosteroids and muscarinic antagonists in human airways. Pulm Pharmacol Ther 2016; 36: 1-9.

30. Cazzola M, Calzetta L, Puxeddu E, Ora J, Facciolo F, Rogliani $P$, et al. Pharmacological characterisation of the interaction between glycopyrronium bromide and indacaterol fumarate in human isolated bronchi, small airways and bronchial epithelial cells. Respir Res 2016; 17(1): 70.

31. 31. Rogliani P, Matera MG, Facciolo F, Page C, Cazzola M, Calzetta L. Beclomethasone dipropionate, formoterol fumarate and glycopyrronium bromide: Synergy of triple combination therapy on human airway smooth muscle ex vivo. Br J Pharmacol 2020; 177(5): 1150-63.

32. Papi A, Virchow JC, Singh D, Kots $M$, Vele A, Georges $G$, et al. Extrafine triple therapy and asthma exacerbation seasonality: TRIMARAN and TRIGGER post hoc analyses. J Allergy Clin Immunol 2021; 148(1): 262-5.e2.

33. Gessner C, Kornmann O, Maspero J, van Zyl-Smit R, Krüll $M$, Salina A, et al. Fixed- dose combination of indacaterol/ glycopyrronium/mometasone furoate once-daily versus salmeterol/fluticasone twice-daily plus tiotropium oncedaily in patients with uncontrolled asthma: A randomised, Phase IIIb, non-inferiority study (ARGON). Respir Med 2020; 170: 106021. 
34. Virchow JC. Assessing the benefits of triple versus dual fixed-dose combinations for the treatment of severe asthma. Lancet Respir Med 2020; 8(10): 937-9.

35. Rogliani P, Ritondo BL, Calzetta L. Triple therapy in uncontrolled asthma: a network meta-analysis of Phase III studies. Eur Respir J 2021; 2004233.
36. Drugs.com. Trelegy Ellipta FDA Approval History. Available from: https://www.drugs.com/history/trelegyellipta.html (Accessed date: 1 Apr 2021).

37. European Medicines Agency (EMA). Trelegy Ellipta. Available from: https://www.ema.europa.eu/en/medicines/human/summaries-opinion/trelegy-ellipta-0 (Accessed date: 1 Apr 2021). 